\title{
PERSEPSI MASYARAKAT TERHADAP PENGELOLAAN DANA DESA DALAM MENINGKATKAN KESEJAHTERAAN MASYARAKAT (Studi Kasus Di Desa Romean Kecamatan Yaru Kabupaten Maluku Tenggar Barat) \\ Oleh: \\ Monica Feronica Bormasa \\ (STIA Saumlaki)
}

\begin{abstract}
This study aims to determine the perceptions of the people of Romean Village, Yaru District, West Southeast Maluku Regency on the management of village funds to improve the welfare of the village community. This research conducted a discretive caulitative approach using the analysis flow from Millis and Huberman. The technique of collecting data is through interviews with village government officials and several community members as informants. The results showed that Village Fund Management was not optimal because of low human resources, low level of community participation in village program planning, low supervision, lack of accountability and transparency in managing village funds, and finally the impact of village funds on community welfare was still low.
\end{abstract}

Keywords: Community Perception and Village Fund Management

\begin{abstract}
Abstrak
Penelitian ini bertujuan untuk mengetahui persepsi masyarakat Desa Romean Kecamatan Yaru Kabupaten Maluku Tenggara Barat terhadap pengelolaan dana desa untuk peningkatan kesejahteraan masyarakat desa. Penelitian melakukan pendekatan kaulitatif diskritif dengan menggunakan alur analisis dari Millis dan Huberman. Teknik pengumpulan data melalui wawancara terhadap aparatur pemerintah desa dan beberapa anggota masyarakat sebagai informan. Hasil penelitian menunjukan bahwa Pengelolaan Dana Desa belum maksimal karena rendahnya SDM, tingkat partisipasi masyarakat rendah dalam perencanan program desa, rendahnya pengawasan, tidak adanya akuntabilitas dan transparan pengelolaan dana desa, dan akhirnya dampak dana desa bagi kesejahteraan masyarakat masih rendah,
\end{abstract}

Kata Kunci : Persepsi Masyarakat dan Pengelolaan Dana Desa 
PENDAHULUAN

Negara Indonesia merupakan

negara kesatuan yang dalam penyelenggaraan pemerintahannya saat ini menganut asas desentralisasi, dekonsentrasi, dan tugas pembantuan. Asas ini berdasarkan pada UndangUndang No. 79 tahun 2005 tentang Pedoman Pembinaan dan Pengawasan Penyelenggaraan Pemerintahan Daerah.

Berdasarkan Undang-Undang tersebut hal ini berarti bahwa pemerintah Indonesia memberikan kekuasaan dan kesempatan kepada setiap daerah otonom untuk menjalankan otonomi daerahnya masing- masing guna mempercepat laju pertumbuhan ekonomi dan pembangunan nasional (Jurnaidi, Djumadi, dan Paranoan, 2015). Kebebasan wilayah otonom untuk mengatur dan menentukan sendiri kebijakan-kebijakan pembangunan daerah merupakan strategi baru yang diterapkan oleh pemerintah setelah kegagalan penerapan kebijakan pembangunan pada masa orde lama dan orde baru.

Dalam sistem pemerintahan Indonesia saat ini negara telah memberikan wewenang kepada pemerintah daerah melalui otonomi daerah untuk mengatur penyelenggaraan pemerintahan di daerah tersebut. UndangUndang Nomor 23 Tahun 2014 menjadi dasar pemerintah daerah diberikan hak untuk mengatur semua penyelenggaraan pemerintahan di luar kewenangan pemerintah pusat seperti politik luar negeri, moneter dan fiskal, urusan agama serta pertahanan dan keamanan.

Pemerintah daerah dalam menyelenggarakan pemerintahan diberikan kewenangan melalui asas desentralisasi untuk mengatur rumah tangganya sendiri guna menekankan prinsip-prinsip demokrasi, peran serta masyarakat, pemerataan, keadilan serta dengan memperhatikan potensidan keanekaragaman daerah. Desentralisasi tidak hanya terbatas pada tingkat kabupaten kota tetapi sampai ke tingkat desa.

Desa merupakan representasi dari kesatuan masyarakat hukum terkecil yang telah ada dan tumbuh berkembang seiring dengan sejarah kehidupan masyarakat Indonesia dan menjadi bagian yang tidak terpisahkan dari tatanan kehidupan bangsa Indonesia. Berdasarkan Undang-Undang Nomor 6 Tahun 2014 Tentang Desa, negara memberikan kebijakan penataan dan pengaturan mengenai desa dalam menjalankan fungsi dan kewenangan desa serta memperkuat kedudukan desa dan masyarakat desa sebagai subjek pembangunan.

Desa sebagai organisasi terkecil dalam Sistem Pemerintahan Negara Kesatuan Republik Indonesia, juga membutuhan sosok seorang pemimpin 
yang mampu untuk menggerakan anak buahnya sehingga bekerja secara optimal dengan meningkatkan kemampuan dan prestasi kerja. Desa sebagai ujung tombak pembangunan dan kesejahteraan masyarakat diberikan wewenang dan dana yang memadai agar dapat mengelola potensi yang dimilikinya guna meningkatkan ekonomi dan kesejahteraan masyarakat (Alaslan, 2021: 98)

Salah satu program yang mendukung kesejateraan masyarakat saat ini adalah dana desa yaitu pemerintah mengalokasikan dana sebagai salah satu sumber keuangan di desa. Salah satu manfaat dari pada dana desa adalah untuk meningkatkan kesejateraan masyarakat namun Hal tersebut belum tergambar pada Desa Romean Kecamatan Yaru Kabupeten Maluku Tenggara Barat yang mana belum sama sekali terlihat bahawa anggaran dana desa yang diberikan oleh pemerintah dapat membantu meningkatkan kesejateraan masyarakat miskin yang ada pada desa tersebut.

Masih banyaknya persepsi masyarakat yang mengeluh dengan pengunaan anggaran desa yang tidak tepat sasaran, yakni ada janda anak yatim piatu yang tidak menerima bantuan dari pemerintah desa, bahkan nyaris anggaran dana desa berupa bantuan pemerintah lebih terfokus bagi masyarakat yang dikategorikan sebagai masyarakat yang mampu mapun kelompok-kelompok terdekat dari pada pemerintah desa, untuk itu yang menjadi prinsip dasar dalam penelitian ini adalah:

1. Masih ada kemiskinan dan kesenjangan di diesa.

2. Masyarakat di desa sepenuhnya belum diberdayakan oleh dana desa

3. Minimnya SDM Perangkat Desa dan BPD tentang kebijakan pengelolaan dana desa.

Hal ini membuat masyarakat yang tidak mampu, atau masyarakat miskin meresa tidak diperhatikan oleh pemerintah desa sama sekali, dari pengamatan yang dilakukan pada Desa Romean Kecamatan Yaru Kabupaten Maluku Tenggara Barat ini maka perluh diteliti lebih jelas tentang Persepsi Masyarakat Terhadap Pengelolaan Anggaran Desa Dalam Meningkatkan Kesejahteraan Masyarakat (Studi Kasus Pada Desa Romean Kabupaten Maluku Tenggara Barat).

\section{TINJAUAN PUSTAKA}

\section{Konsep Masyarakat}

Dalam memahami konsep persepsi masyarakat, sebaiknya terlebih dahulu kita paham siapa yang berpersepsi tersebut, yaitu masyarakat. Definisi dan pengertian mengenai masyarakat telah banyak dikemukakan oleh para antropologi dan sosiologi. 
Menurut Robert Mac Iver, masyarakat adalah "suatu sistem hubungan-hubungan yang ditertibkan (Society means a system of ordered relations)" (dalam Budiardjo, 2002).

Beberapa pengertian tentang masyarakat tersebut dikemukakan dalamSoejono Soekanto (2003) dengan mengutip pendapat para ahli antara lain :

1) "Masyarakat adalah suatu sistem dari kebiasaan dan tatacara, dari wewenang dan kerja sama antara berbagai kelompok dan penggolongan, dan pengawasan tingkah laku serta kebebasankebebasan manusia. Keseluruhan yang selalu berubah" (Mac Iver dan Page).

2) "Masyarakat merupakan setiap kelompok manusia yang telah hidup dan bekerja bersama cukup lama sehingga mereka dapat mengatur diri mereka dan menganggap diri mereka sebagai suatu kesatuan sosial dengan batas-batas yang dirumuskan dengan jelas" (Ralph Hinton).

3) "Masyarakat adalah orang-orang yang hidup bersama, yang menghasilkan kebudayaan"

Berdasarkan pengertian di atas dapat ditarik kesimpulan, bahwa masyarakat merupakan kelompok manusia sebagai satu kesatuan dan merupakan satu sistem yang menimbulkan kebudayaan dan kebiasaan di mana setiap orang merasa terikat satu sama lain yang mencakup semua hubungannya baik dalam kelompok maupun individu di dalam satu wilayah. Selain itu masyarakat dapat juga disimpulkan sebagai kesatuan hidup manusia yang berinteraksi menurut sistem adat tertentu yang bersifat kontinyu dan yang terkait oleh suatu rasa identitas bersama.

\section{Persepsi Masyarakat}

Kata "Persepsi" seringkali digunakan dalam kehidupan sehari-hari, yang merujuk pada proses pemberian arti atau makna terhadap informasi, peristiwa, objek dan lainnya yang berasal dari lingkungan sekitar oleh individu atau masyarakat dalam kehidupan sehari-hari, sehingga persepsi dapat diartikan sebagai pandangan masyarakat yang diperoleh lewat suatu interaksi sosial, kehidupan yang riil di masayarakat serta pengalaman yang dialami sehingga persepsi dapat dikatakan sebagai suatu proses penginderaan, stimulus yang diterima oleh individu melalui alat indera yang kemudian diinterpretasikan sehingga individu dapat memberikan pandangan, memahami dan dapat mengartikan tentang stimulus yang diterimanya (Alaslan, 2021: 5).

Menurut Robbins (1998) "Persepsi adalah proses di mana sesorang 
mengorganisir dan menginterpretasikan kesan dari panca indra dalam tujuan untuk memberikan arti bagi lingkungan mereka”. persepsi juga dapat diartikan sebagai pandangan terhadap pelayanan yang elah diterima oleh masyarakat. Persepsi akan menjadi lebih kuat ketika semua fakta yang dialami oleh masyarakat, dapat diorganisir secara baik melalui panca indera. Dengan demikian, persepsi masyarakat timbul dari berbagai kenyataan atau peristiwa yang dialami atau dirasakan oleh setiap orang lewat panca indera.

Menurut Sehiffman dan Kanuk (2007), "persepsi adalah "suatu proses di mana seseorang memilih, mengorganisasikan, dan mengartikan masukan informasi yang diterima menjadi suatu gambaran yang penuh arti dan saling terkait".

Persepsi tidak hanya tergantung pada sifat-sifat rangsangan fisik, tapi juga dari pengalaman dan sikap dari individu. Pengalaman dapat diperoleh dari semua perbuatannya di masa lampau atau dapat pula dipelajari, sebab dengan belajar seseorang akan dapat memperoleh pengalaman.

$$
\text { Jalaludin Rakhmat }
$$

mengemukakan bahwa "Persepsi adalah pengalaman tentang objek, peristiwa atau hubungan-hubungan yang diperoleh dengan menyimpulkan informasi dan menafsirkan pesan".

\section{Pengelolaan Dana Desa}

Menurut Peraturan Menteri

Keuangan RI Nomor 49/PMK.07/2016 Tentang Tata Cara Pengalokasian, Penyaluran, Penggunaan, Pemantauan, dan Evaluasi Dana Desa, Bab I Ketentuan Umum Pasal 1 ayat 2 dijelaskna bahwa "Dana Desa adalah dana yang bersumber dari Anggaran Pendapatan dan Belanja Negara yang diperuntukkan bagi desa yang ditransfer melalui Anggaran Pendapatan dan Belanja Daerah kabupaten/ kota dan digunakan untukmembiayai penyelenggaran pemerintahan, pelaksanaan pembangunan, pembinaan kemasyarakatan, dan pemberdayaan masyarakat". Selanjutnya Alokasi Dana Desa dijelaskan dalam Bab I Ketentuan Umum Pasal 1 Ayat 3 bahwa "Alokasi dana desa merupakan alokasi minimal dana desa yang akan diterima oleh setiap desa, yang besarannya dihitung dengan cara 90 persen dari Anggaran Dana Desa dibagi dengan jumlah desa secara nasional" (PMK, 2016).

\section{Asas Pengelolaan Dana Desa}

Fungsi dana desa atau yang biasa dikenal dengan istilah DD adalah untuk meningkatkan kesejahteraan dan pemerataan pembangunan desa. Dana 
desa yang diperuntukkan bagi pembangunan serta pemberdayaan masyarakat harus diolah serta digunakan dengan baik dan tepat guna oleh pemerintah desa sebagai penyelenggara pemerintahan di desa. Pada pelaksanaan pembangunan serta pemberdayaan desa dalam rangka mengimplementasikan dana desa yang ada harus sesuai dengan asas pengelolaan dana desa yang telah ditentukan. Berdasarkan Permendagri No. 113/2014, Bab II Pasal 2 Ayat (1) tentang Pengelolaan Keuangan Desa dijelaskan bahwa pengelolaan keuangan desa termasuk dana desa harus sesuai asas pengelolaan yaitu transparansi, akuntabel, partisipatif, serta tertib dan disiplin anggaran (Keuangan desa, 2015). Asas pertama yaitu partisipatif yang artinya dalam proses pengelolaan anggaran serta pelaksanaan pembangunan di desa tidak hanya melibatkan kaum elit desa (pejabat pemerintah desa) tetapi juga harus melibatkan masyarakat lokal baik pemuda, perempuan,petani dan lain sebagainya untuk dapat menciptakan pembangunan yang tepat guna. Asas yang kedua yaitu Akuntabel artinya perwujudan kewajiban untuk mempertanggung jawabkan pengelolaan dan pengendalian sumber daya, dan pelaksanaan kebijakan yang dipercayakan dalam rangka pencapaian tujuan yang telah ditetapkan (BPKP, 2015). Ketiga yaitu Transparansi yang artinya keterbukaan, semua pihak dapat melihat keseluruhan informasi dari penggunaan anggaran. Hak untuk mengetahui tentang keuangan desa dengan adil, jujur, dan tanpa diskriminasi. Terakhir yaitu tertib dan disiplin anggaran yang artinya pengelolaan keuangan desa harus mengacu pada aturan atau pedoman yang melandasinya (Renyowijoyo,2013).

Berdasarkan penjabaran terkait asas pengelolaan dana desa di atas maka sudah seharusnya dalam implementasi kebijakan dana desa harus melibatkan asas tersebut sebagai wujud pengelolaan yang baik. Implementasi dana desa terkait pembangunan yang dilaksanakan di desa harus melibatkan asas pengelolaan karena dengan adanya partisipasi, akuntabel, transaparansi, serta tertib dan disiplin aggaran dalam pengelolaannya kebijakan yang diterapkan akan lebih tepat guna. Selain itu, penyusunan Rencana Kerja Pemerintah (RKP) Desa yang ditetapkan oleh desa harus dilakukan dengan mengadakan musyawarah desa, sehingga dalam hal ini partisipasi masyarakat menjadi aspek penting dalam penentuan kebijakan pembangunan desa (Kemendesa, 2016). Lebih lanjut Kemendesa (2016) juga menjelaskan bahwa partisipasi masyarakat yang harus ada dalam implementasi kebijakan di desa adalah sebagai pendamping dalam 
pembangunan desa dan pemantau ketepatan praktik penerapan program oleh pemerintah desa. Berdasarkan hal tersebut maka dalam pelaksanaan pembangunan desa, masyarakat lokal tidak dapat diabaikan partisipasinya dan tidak hanya dijadikan sebagai objek pembangunan.

\section{METODE PENELITIAN}

Penelitian dilakukan di Desa romean, Kecamatan Yaru Kabupaten Maluku Tenggara Barat. Data dikumpulkan melalui wawancara mendalam. Informan adalah Kepala Desa, aparatu pemerintah desa dan masyarakat Desa Romean Selanjutnya data dianalisis mengikuti alur penelitian kualitatif. Menurut Milles dan Huberman dalam Alaslan, (2021: 7) bahwa dalam penelitian kualitatif terdapat tiga alur kegiatan yang terjadi secara bersamaan yaitu : reduksi data, penyajian data, dan penarikan kesimpulan.

\section{HASIL DAN PEMBAHASAN Pengawasan Lemah}

Fungsi pengawasan dalam pengelolaan dana desa masih belum terlihat berjalan dengan baik, yaitu fungsi kontrol pemerintah daerah dalam hal ini desa, dimana pos anggaran untuk program pemberdayaan masyarakat belum terarah dengan baik, anggaran yang diberikan untuk pengembangan pemberdayaan masyarakat desa hanya terpusat pada kelompok atau pribadi- pribadi keluarga dan kerabat aparatur pemerintah desa sehingga mengabaikan masyarakat miskin yang benar-benar membutukan bantuan dari pada dana desa tersebut.

\section{Kualitas SDM Rendah}

Minimnya SDM dalam mengambil Kebijakan Pengelolaan Dana Desa adalah salah satu faktor utama dampak dari pada Pengelolaan Dana desa. Dalam meningkatkan kesejateraan masyarakat miskin salah satu peran penting pemerintah desa adalah mengambil kebijakan terhadap pengelolaan dana desa, untuk sebuah pengambilan kebijakan dibutukannya SDM yang mampu berpikir, bertindak dengan bijak dan memiliki pengetahuan yang cukup baik dalam pengembilan kebijakan, karena sebuah kebijakan dari pada pemerintah desa adalah keputusan terpenting untuk masyarakat miskin, namun pada kenyataannya SDM pada Pemmerintah desa belum mampu mengambil kebijakan secara tepat terhadapat pengelolaan Dana desa mengakibatkan masyarkat menjadi korban pengambilan kebijakan yang salah sasaran.

\section{Rendahnya Partisipasi Masyarakat Dalam Perencanaan}

Tidak ada keterlibatan masyarakat 
dalam musrembang desa untuk penyusunan program kerja. Agar tercapainya perncanaaan program pemerintah desa bagi masyarakat miskin, maka pemerintah desa dalam penyusuanan rencana program kegiatan dapat melibatkan masyarakat desa dalam penyusunan program kerja sehingga seluru masalah dan aspirasi masyarakat desa dapat terjawab melalui program kerja tersebut, sehingga pemerintah desa tidak semata-mata merencanakan dan mengelola dana desa sesuai keinginan dan kepentingan kelompok.

\section{Pemerintah Desa Tidak Akuntabel Dan Transparan Dalam Pengelolaan Dana} Desa.

Akuntabilitas merupakan suatu istilah yang pada awalnya diterapkan untuk mengukur apakah Dana publik telah digunakan secara tepat dengan tujuan dimana dana publik tadi ditetapkan dan tidak digunakan seacar ilegal. Akuntabilitas adalah sebuah pertanggung jawaban dari pemerintah yang mengatur adaministrasi publik, jadi dalam akuntabiltas memuat kewajiban untuk memaparkan atau melaporakan segala tindakan dan aktivitas yang di lakukan di bidang administrasi keuangan.

Pemerintah Desa Romean dalam pengelolaannya tidak akuntabel, pengunaan anggaran tidak tepat sasaran dan juga dalam pertanggung jawabnya tidak diketahui oleh masyarakat sehingga masyarakat merasa bahwa dana desa hanya symbol dari pada peningkatan kesejahteraan masyarakat. Desa dalam pengelolaan keuanganya sangat diharapkan agar transparan dalam pengelolaan keuangan Desa, karena transparansi keuangan desa merupakan jembatan penghubung terciptanya kepercayaan masyarakat terhadap seluruh penyelengaraan keuangan desa, sebaliknya bila penyelengaraan pemerintah itu transparan maka masyarakat akan merasa percaya terhadap kinerja pemerintah desa dalam pengelolaan dana desa.

\section{Masyarakat Desa Belum Merasakan Dampak Positif Dari Pengelolaan Dana} Desa.

Dana Desa digunakan untuk mensejahterakan masyarakat, menciptakan lapangan kerja, mengatasi kesenjangan dan mengentaskan kemiskinan, untuk tercapainya kesejahteraan masyarakat maka pemerintah desa dapat menyelengarakan pencapaian tujuan dari pada dana desa dengan merencanakan, mengelola dan mengawal Dana Desa agar dapat perpihak pada masyarakat miskin dan dapat mewujudkan tujuan dari pada dana desa namun masyarakat desa romean sama 
sekali tidak merasakan dampak positif dari pada dana desa, karena sebagian dana desa gunakan untuk kepentingan kelompok dan pribadi.

Untuk itulah maka Pemimpin harus betintak sebagai motor atau daya penggerak dari semua sumber-sumber dan alat-alat (resources) yang tersedia dalam suatu organisasi agar dapat menyelaraskan visi misi lembaganya dalam memberikan pelayanan kepada masyarakat tanpa berlandaskan pertukaran kepentingan semata. Karena pada prinsipnya Kepemimpinan merupakan inti manajemen, karena kepemimpinan merupakan motor atau daya penggerak semua sumber-sumber dan alat-alat (resources) yang tersedia sebagai suatu organisasi (Alaslan, 2021: 99).

\section{KESIMPULAN}

Berdasarkan hasil Penelitian dan Analisis data maka kesimpulan terhadap penelitian ini adalah Pengelolaan dana desa pada Desa Romean masih sangat jauh dari harapan masyarakat, sehingga dapat menurunkan kepercayaan masyarakat pada pemerintah desa dalam mengelola dana desa, hal ini dapat di lihat pada hasil penelitian bahwa masyarakat desa sangat tidak merasakan dampak dari pada dana desa, sedangkan yang diketahui bersama bahwa dana desa adalah anggaran yang di berikan oleh pemerintah pusat kepada pemerintah desa sebagai penagnggung jawab pemerintahan pada desa adalah untuk mensejahterkan masyarakat, namun hal ini sangat disyangkan jika tidak sesuai dengan harapan, pada hal setiap tahun pemerintah desa menerima bantuan dan meberikan laporan yang baik kepada pemerintah pusat namun sangat disayangkan jika laporan penggung jawaban itu hanya hasil yang direkayasa oleh penyelenggara pemerintah desa, karena pemerintah desa juga tidak transparan dan akuntabel dalam pengelolaannya, fungsi kontrol dari Kecamatan juga belum berjalan dengan baik bahkan Fungsi kontrol dari Dinas Pemberdayaan Masyarakat Desa juga belum memenuhi ketentuan yang diinginkan sehingga kesalahan-kesalahan yang diberikan oleh pemerintah kepada masyarakat desa akan terus terjadi.

\section{SARAN}

1. Fungsi Kontrol dari Dinas Pmberdayaan Masayarkat Desa pada Kabupaten Maluku Tenggara Barat perlu ditingkatkan dengan memberih tugas peneyelidikan terhadap pelaopran-pelaporan pengelolaan Dana Desa yang di sampaikan oleh Pemerintah Desa Romean

2. Pendamping Desa dan Pendamping Lokal Desa yang di bawah 
Kementrian Desa yang ditugaskan untuk mendampingi pemerintah desa dalam pengelolaan anggaran desa mohon agar tidak hanya fokus pada pengunaan anggarannya saja namun mohon agar mendampingi pemerintah desa juga dalam penysunan program kerja yang melibatkan semua unsurunsur desa namun juga seluruh masyarkat agar merka dapat menyampaikan aspirasinya.

3. Masyarakat Desa Romean harus mendapatkan informasi penggunaan dana desa melalui Iklan, (Baliho atau Papan Informasi) sehingga pengunaan dana desa transparan dan akuntabel dan juga dapat mengembalikan kepercayaan masyarakat desa kepada pemerintah sehingga dapat meningkatkan pasrtisipasi masyarakat desa dalam membanguan desa melalui pengelolaan dana desa. 


\section{DAFTAR PUSTAKA}

Abidin, M.Z. 2015. Tinjauan Atas Pelaksanaan Keuangan Desa dalam Mendukung Kejikana Dana Desa.Jurnal Ekonomi dan Kebijakan Publik, Vol 6 No.1, 6176.

Alaslan, Amtai. 2021. Gaya Kepemimpinan dan Pembangunan Desa. Journal AdBisPower STIA Saumlaki Vol. 1. No. 1

,2021. Persepsi Masyarakat dan Kepemimpinan Perempuan. Jurnal OTONOMI Ilmu Administrasi Vol. 10. No. 20 ,2021.

Kemampuan Pemerintah Desa Dan Pelaksanaan Tugas Administrasi Pemerintahan. Jurnal OTONOMI Ilmu Administrasi Vol. 9. No. 17

Aziz, N.L. 2017. Otonomi Desa dan Efektivitas Dana Desa. Jurnal Penelitian Politik, 193-211. http://ejournal.lipi.go.id/index.php/j pp/article/view/575/480 di akses pada 18 april 2017.

Hudayana, Bambang.,\& FPPM, Tim. 2005. Peluang Pengembangan Pertisipasi Masyarakat Melalui Kebijakan Alokasi Dana Desa.http://ejournal.narotama.ac.id /files/Peluang\%20Pengembangan\% 20Partisipasi\%20Masyarakat $\% 20 \mathrm{~m}$ elalui\%20ADD.pdf.Di akses 27 September 2016.

John M Caken dan Norma T. Uphaff, 1987, Partisipasi Sosial suatu pendekatan teoritis oleh garuda sunarsih, FISIP UGM, Jogjakarta.

Moleong J Lexy, 2002., Metodologi Penelitian Kualitatif, Penerbit Remaja Rosda karya, cetakan Ke XVIII.

Nafidah, L.N., \& Suryaningtyas, M. 2015., Akuntabilitas Pengelolaan Alokasi Dana Desa dalam Meningkatkan Pembangunan dan
Pemberdayaan Masyarakat. Bisnis, 214239.53http://journal.stainkudus. ac.id/index.php/Bisnis/article/view/ 1480/1351D i akses 10 September 2016.

Oberlin Silalahi, 1982 Beberapa Aspek Kebijaksanaan Negara, Liberty Bandung,

Utra, C.K., Pratiwi, R.N., \& Suwondo. 2014., Pengelolaan Dana Desa dan Pemberdayaan Masyarakat Desa (Studi di Desa Wonorejo Kecamatan Singosari Kabupaten Malang.Jurnal Administrasi Publik (JAP) , 12031212.

Undang-Undang No. 79 Tahun 2005 tentang Pedoman Pembinaan dan Pengawasan

Penyelen ggara Pemerintah Daerah

Sugiyono, 2009, Metode Penelitian Pendidikan Kualitatif dan Kuantitatif, Bandung: Alfabeta

Undang-Undang No. 6 Tahun 2014 tentang Desa

Peraturan Pemerintah No. 22 Tahun 2015 tentang Dana Desa

Peraturan Menteri Keuangan No. 247/PMK.07/2015 tentang Tata Cara Pengalokasian, Penyaluran, Penggunaan, Pemantauan dan Evaluasi Dana Desa 